\title{
The Effect of Human Resources Management Skills on Accounting Information Quality in Kurdistan Public Sector
}

\author{
Khowanas Saeed Qader ${ }^{1}$, Bayar Ali Ismeal ${ }^{2}$, Hassan Mahmood Aziz ${ }^{3}$, Pshdar Abdalla \\ Hamza $^{4}$, Sarhang Sorguli ${ }^{5}$, Bawan Yassin Sabir ${ }^{6}$, Govand Anwar ${ }^{7}$, Bayar Gardi ${ }^{8}$
}

\author{
${ }^{1}$ Department of accounting and finance, College of Administrations and economics, Lebanese French university, Kurdistan region, Iraq \\ ${ }^{2}$ Department of Accounting, Erbil Technical College, Erbil Polytechnic University. \\ ${ }^{3}$ Department of Accounting and Finance, Faculty of Economics and Administrative Sciences, Cyprus International University, Mersin 10, \\ Haspolat 99040, Cyprus. \\ ${ }^{4}$ Department of Business Administration, Kurdistan Technical Institute, Sulaymaniyah, Iraq. \\ ${ }^{5}$ Department of Accounting, College of Administration and Financial Sciences, Knowledge University, Kirkuk Road, 44001 Erbil, \\ Kurdistan Region, Iraq. \\ ${ }^{6}$ Department of Accounting, College of Administration and Financial Sciences, Knowledge University, Kirkuk Road, 44001 Erbil, \\ Kurdistan Region, Iraq. \\ ${ }^{7}$ Department of Business Administration, College of Administration and Financial Sciences, Knowledge University, Kirkuk Road, 44001 \\ Erbil, Kurdistan Region, Iraq. \\ ${ }^{8}$ Department of Accounting, College of Administration and Financial Sciences, Knowledge University, Kirkuk Road, 44001 Erbil, \\ Kurdistan Region, Iraq. Email: bayar.gardi@knu.edu.iq , https://orcid.org/0000-0001-9724-7250
}

Received: 11 May 2021; Received in revised form: 08 Jun 2021; Accepted: 16 Jun 2021 (C)2021 The Author(s). Published by TheShillonga. This is an open access article under the CC BY license (https://creativecommons.org/licenses/by/4.0/)

\begin{abstract}
The article's purpose is to measure the impact of human resources management skills on accounting information quality in kurdistan public sector. To enable the study to measure human resource management skills at public sectors in Kurdistan region of Iraq, the researchers used five human resources management skills elements, first is communication skill, second is flexibility skill, third is negotiation skill, fourth is ethical action skill, and fifth is compassion skill. To assess the current study, the researchers used a quantitative research method in the form of a survey. The questionnaire was delivered at random to 84 administrative employees from several government departments in the Kurdistan region. The researchers, on the other hand, were able to collect 78 completed questionnaires. The results showed that as for the impact of communication skill on accounting information system was found the value of Beta is .632 with significant level .000 this indicated that first research hypothesis is supported which is Communication skill as human resource management skills has a positive and significant influence on accounting information system. As for the impact of Flexibility skill on accounting information system was found the value of Beta is .611 with significant level .000 this indicated that second research hypothesis is supported which is Flexibility skill as human resource management skills has a positive and significant influence on accounting information system. As for the impact of Negotiation skill on accounting information system was found the value of Beta is .642 with significant level .000 this indicated that third research hypothesis is supported which is Negotiation skill as human resource management skills has a positive and significant influence on accounting information system. As for the impact of Ethical actions skill on accounting information system was found the value of Beta is .649 with significant level .000 this indicated that fourth research hypothesis is supported which is Ethical actions skill as human resource management skills has a positive and significant influence on accounting information system, and lastly, as for the impact of Compassion skill on accounting information system was found the value of Beta is .661 with significant level .000 this indicated that fifth research hypothe sis is supported which is Compassion skill as human resource management skills has a positive and significant influence on accounting information system.
\end{abstract}


Keywords-Human Resource Management Skill, Accounting Information System, Public Sector, Kurdistan Region of Iraq .

\section{INTRODUCTION}

Accounting information is used by all types of commercial and non-profit organizations to assist stakeholders, both within the company as managers and externally, such as investors, government agencies, banks, and others, in making economic decisions (Sousa, 2017). Accounting information is used to assist outside organizations in making investment decisions, evaluating performance, monitoring activity, and as a regulatory measure (regulatory measures) (Mazurchenko \& Maršíková, 2019). The act of discovering and quantifying data regarding human resources and distributing this information to interested parties is known as human resource accounting. Gardi, 2021) define human resource accounting as the quantification in monetary terms of an organization's human resources and argue that a welldeveloped system of human resource/capital accounting could significantly contribute to internal management decisions and external investor decisions.

Accounting Information System capable of integrating subsystems or components of both physical and nonphysical interconnectedness and functioning in harmony to convert transaction data relating to financial difficulties into financial information. Accounting information systems should be capable of collecting data, transforming data into information, and disseminating information to internal and external users. According to Ismael, et al. 2021), one of the criteria determining the effectiveness of the accounting information system installation is managerial commitment. (The top five reasons for the success of the new "Accounting Information System" deployment are: (a) user interaction, (b) executive management support, and (c) a clear explanation of needs. (d) Thorough planning and (e) reasonable expectations). Sorguli \& Al-Kake, 2020) discovered that the commitments related to sustaining behavior management in order to achieve goals and increase the efficacy of the accounting information system. Furthermore, according to Al Shobaki, et al. 2017), management commitment is a key aspect in the installation of information systems, and consistency of support will simplify the utilization of the resources required for operations. Damit, et al. 2019) further verified that, in addition to infrastructure, Indonesia is today confronted with challenges that may impede future economic growth, including the quality of Human Resources (HR). Almost all emerging countries, including Indonesia, perceive competent human resources to be a problem. When compared to neighboring countries, human resources in Indonesia have traditionally been of high quality (Tambe, et al. 2019).
Human resources, as system users, must have a sufficient level of accounting experience or the ability to continue to learn and improve accounting skills. The ability of human resources was crucial in generating significant information in this case (Ali \& Anwar, 2021). The problems in the Lebak area are a lack of quality human resources, a lack of finance capacity in the area, and a lack of widespread knowledge of appropriate technology, all of which cause the rate of economic growth, particularly in the Lebak area government environments, to slow significantly (De Mauro, et al. 2018).

Financial accounting information is the result of corporate accounting and external reporting systems that measure and frequently reveal audited, quantitative data about publicly traded companies' financial situation and performance. The core of the firm-specific information set available to investors and regulators is comprised of audited balance sheets, income statements, and cash-flow statements, as well as supporting disclosures (Gardi, 2021). It is not cheap to create and maintain a sophisticated financial disclosure framework. Countries with highly developed securities markets invest heavily in developing and enforcing comprehensive accounting and disclosure regulations that publicly traded corporations must comply. The resources expended include not only financial expenditures, but also opportunity costs connected with the deployment of highly educated human capital, such as accountants, lawyers, academicians, and politicians (Hakim \& Kessentini, 2017).

Talent management is a term that refers to the group of people that make up an organization's or commercial entity's workforce. According to Syed Kutnjak, et al. 2019), it consists of people's energies, skills, talents, and knowledge that are, or can potentially be, devoted to the creation of commodities or the provision of useful services (Ismael, et al. 2021). Because the ability of human resources to effectively and efficiently utilize other resources such as land, equipment, and money is critical to the success of any organization, human resources are the most valuable assets at the disposal of organizations. This is why, in most organizations' annual reports, the remark "our greatest assets are our employees" is included (Saleh, et al. 2021).

Accounting information systems play a fundamental role in organizations by processing accounting data and producing quality accounting information to support the company's internal activities carried out by managers and employees, as well as company activities with outsiders such as consumers, government suppliers, and others. Management inside an organization use business techniques to deliver added value in order to get a competitive advantage (Gardi, 2021). Global competition and change with flexibility 
(Sorguli, et al. 2020), adaptability, and innovative power have become management needs due to the pressure of change from increasing globalization and international trade, rapid technological changes, changes in cultural values, labor diversity, use of outsourcing, use of social networks, and use of virtual interactions (Ali, et al. 2021).

Managers and many business professionals receive information from information systems in the form of reports and displays (Abdullah \& Anwar, 2021). People, hardware, software, data, and network resources are all used by information systems to execute input, processing, output, storage, and control activities that convert data resources into information. The information system is a set of formal processes that govern how data is acquired, processed, and provided to consumers (Omoraka, 2020).

According to Anwar, (2017), accounting is a system for providing quantitative information, particularly of a financial kind, about an economic institution that is supposed to be useful in making economic decisions. Management accounting refers to the process of giving information, both financial and non-financial, to managers and staff of an organization in order enable them to make choices, allocate resources, monitor, and evaluate its performance (Mirsafian, 2019).

Responsibility and management for efficiency/costeffectiveness have proven to be the most difficult challenges in a variety of initiatives where money are routed. Project sustainability has been identified as a severe issue, and there is little information available about project sustainability other than how they were implemented (Panagiotopoulos \& Karanikola, 2017). Attention has been focused on ensuring that nongovernmental organization initiatives, both national and international, are accountable for the funds obtained and spent to all stakeholders of the organization in order to aid them in managing resources (avoiding fraud) and making decisions. Nongovernmental organizations' projects are mostly funded by development partners. Leaders of nongovernmental organizations have emphasized the importance of development partners' expectations and financial accounting in their present accountability processes (Anwar \& Qadir, 2017). Accountability has been seen as a foundation for achieving effectiveness in facilitating monitoring programs and projects (Anwar \& Climis, 2017). Nongovernmental organizations' responsibility to funders is quite strong, as evidenced through reports and evaluations. As a tool of accountability and decision making, the funding agency required projects to publish periodic financial reports for the monies they raised and spent. Financial accounts are a driving force in the development of SMEs. An accounting information system (AIS) is a management information system (MIS) subsystem that plays critical roles in designing and calculating organizational strategy to strengthen financial control (Ali, et al. 2021). Accounting information systems provide crucial information for stakeholders to make effective decisions, as well as to ensure organizational competitiveness (Silva \& Soares, 2018), influence business strategy implementation (Hameed \& Anwar, 2018), and provide information for corporate sustainability (Sabir, et al. 2021). Furthermore, it helps to reduce fraud and errors in Vietnamese SMEs (Kucuk Bicer \& İlhan, 2020) and enhances the efficiency of the integration process to economic agreements (Abdullah, et al. 2017). However, Vietnamese SMEs lack effective accounting information systems since their information sophistication relies mostly on accounting applications for bookkeeping tasks rather than planning and controlling purposes (Ali, et al. 2021). Furthermore, in terms of technological complexity, a low proportion of SMEs use decision support systems, computer-aided manufacturing, and computer-assisted production management (Gómez, et al. 2021). Because of its significance, the accounting information system has become increasingly involved in management and management control research in recent years (Aziz, et al. 2021).

Skills development predominates as a research topic in the higher education domain since it is the primary goal that students must attain. Skills development is viewed as a strategic management strategy to deal with the contemporary business climate (Sorguli, et al. 2021), owing to the fact that the market has shifted from mass production to customized, with a focus on quality, pricing, and delivery speed (Hamza, et al. 2021).

\section{LITERATURE REVIEW}

\section{Human Resources Management Skills}

The ability to learn and enhance accounting abilities is required for the effective utilization of human resources (Damit, et al. 2019). Human resources played a critical role in uncovering useful information in this instance (Makkos, et al. 2020). Quality human resources, a lack of financing capacity in the area, and a lack of general understanding of proper technology are all key factors that hinder the expansion of the Lebak region government environments. The financial accounting information is the product of public reporting systems as well as the accounting procedures of publicly traded corporations. Balance sheets, income statements, and cash-flow statements are at the heart of the firm-specific information collection that is available to investors and regulators. As a result, maintaining a comprehensive financial disclosure structure is somewhat costly. Many securities-friendly countries engage in heavy 
securities market regulation and enforcement. Public businesses must follow thorough accounting and transparency rules in all these countries. Opportunity costs, which include the money that was spent as well as other opportunities that were missed out on because of the deployment of highly educated human capital, such as accountants, lawyers, academicians, and politicians, are included in the resources expended (Ahmed, et al. 2021).

The set of people who make up an organization's or commercial entity's workforce is referred to as talent management. It is made up of people's human resources, which can be utilized to produce commodities or provide beneficial services. Human resources are vital assets to every company, as human resources have the potential to successfully and efficiently utilize other resources such as land, equipment, and money. As a result, the saying "our greatest assets are our staff" is included in most annual reports. Reports and displays are used to provide information to managers and numerous business professionals. The myriad of entities employed by information systems for input, processing, output, storage, and control operations that turn data resources into information includes people, hardware, software, data, and network resources. A well-organized information system consists of a set of standardized procedures that regulate how data is gathered, processed, and distributed to customers. In numerous projects, costs and efficiency have proven to be the greatest hurdles. It has been noted that the sustainability of projects is a major problem, and no information on project sustainability is accessible except from how they were conducted (Ismael, et al. 2021). While attention has been given to ensuring that NGO initiatives both national and international are accountable for the funds obtained and spent in order to aid stakeholders with management of resources and decision-making, attention has also been paid to assuring that non-governmental organizations adhere to strict rules for financial transactions in order to combat fraud. Development partners are the primary source of nongovernmental organizations' funding. NGO leaders stress the relevance of the expectations and financial accounting of development partners in their current accountability procedures (Ermasova, et al. 2018). Accountability has been considered as a fundamental tool for project and program effectiveness. There are a multitude of reports and evaluations that demonstrate the strength of non-profit organizations' commitments to funders. To meet the expectations of financial responsibility and decisionmaking, funding agencies asked projects to provide regular financial reports (Khati \& Kim, 2020).

\section{Communication Skill}

This skill set is intended to exist across tactics, and the Comskil Model attempts to ensure that it is made apparent in these specific situations. Any other teaching techniques, methods, processes, and evaluations aside from teaching techniques, methods, processes, and evaluations must be separated from the skills being taught. Other techniques described in the article include: the authors highlight how evaluation methods create concordance between abilities taught and those measured through rigorous coding of trainees' communication interactions and clear and direct feedback (Sousa, 2017). There are a number of theories used in the design of communication skills training, the major one being Adult Learning Theory. It has been shown in several sources, including Gardi, (2021) and Ismael, et al. (2021), that numerous key concepts are at work in effective adult learning. These include the following: Adults want to know why they should learn something before starting to learn it, and adults want to learn the practical as well as the theoretical. Adults are motivated to learn in participatory and active settings, and adults prefer responsibility for their decisions and the desire to be viewed as capable of selfdirection. In light of these principles, Sorguli \& Al-Kake, (2020) offer suggestions on optimal learning conditions: starting from within, guiding oneself, incorporating useful resources, using internal motivators, and creating an environment that emphasizes problems and offers opportunities for giving and receiving feedback. To concentrate on the practical problems faced by adult learners, a method that relies on skill development can be highly beneficial.

For successful communication to take place, it is vital that clinicians and customers meet face-to-face. It is possible to come to a mutual agreement on a comprehensive care plan when the customer's requirements and concerns are thoroughly recognized using a biopsychosocial formulation. Communication skills training (CST) has become a vehicle to help clinicians improve their communication skills while simultaneously helping to establish professionalism and outstanding levels of care. While good communication skills have been shown to contribute to higher customer satisfaction, better customer treatment adherence, better health outcomes, fewer malpractice claims, lower anxiety, better recall, and improved understanding, there are no studies proving that good communication skills lead to better health outcomes (Al Shobaki, et al. 2017). Because of this, it is essential to keep track of any and all creation and implementation of communication skills training initiatives. The primary goal of this paper is to investigate how Hulsman et al. addressed criticisms in a new round of literature review on doctor communication skills training. According to Hulsman et al., major gaps exist in the literature on communication skills 
training for practising doctors. A thorough review of existing studies found that many studies utilize inappropriate research methods and that only about half of the communication behaviors are known to result in any sort of positive effect. The Comskil Model ensures that this skill set appears throughout tactics. Separating the approaches, procedures, processes, and evaluations that are being taught from the specific abilities to be learned is required. A number of other strategies were mentioned in the article, including: This book's authors draw attention to how evaluation methodologies have the ability to produce an alignment between the competencies taught and those that are measured through comprehensive coding of trainees' communication interactions and explicit and clear feedback (Damit, et al. 2019).

Various theories on teaching communication skills are utilized in designing a training curriculum, the key one being Adult Learning Theory. A good number of sources concur that when it comes to effective adult learning, several essential concepts are at work. Included in this group are: Many individuals like to know why they should learn something before starting to learn it, while many others would prefer to gain a working knowledge of both theoretical and practical topics. In participatory and active learning environments, people are inspired to learn, and they like to hold the reins when it comes to determining their future. Tambe, et al. (2019) present ideas for effective learning methods based on their observations that start from inside, allow for one's own development, use beneficial resources, put a focus on issues and provides possibilities for providing and getting feedback. Another strategy that focuses on developing certain skills is particularly useful for adult learners (Ali \& Anwar, 2021).

It is crucial that clinicians and customers meet face-to-face in order for successful communication to take place. When the needs and concerns of the customer are understood using a biopsychosocial formulation, it is possible to develop a mutually agreeable care plan. CST has helped clinicians in two ways: First, it improves their communication skills, helping them build professionalism and outstanding levels of care. Second, it serves as a vehicle to improve their communication skills, while also helping to establish professionalism and outstanding levels of care (De Mauro, et al. 2018). While better customer treatment adherence, better health outcomes, and lower anxiety have all been demonstrated to result from better communication skills, no research have proven that stronger communication skills lead to better health results. Since this is true, it is important to record all communication skill training initiatives, no matter how they are implemented. The purpose of this work is to research how (Hakim \& Kessentini, 2017). tackled the criticism that the literature on doctor communication skills training came up against in a new round of literature reviews. Several notable gaps exist in the research on teaching doctors in communication skills, claims Hulsman et al. The results of an exhaustive literature study indicated that many studies apply inadequate research methodologies, and the result is that less than half of communication activities have been positively proven to result in any form of effect (Kutnjak, et al. 2019).

\section{Flexibility}

The mental and emotional flexibility model incorporates acceptance as a means of implementing a different strategy for the utilization of experiential avoidance, which is identified by a pattern of behaviors observed when someone does not permit themselves to experience thoughts, feelings, memories, or sensations (Saleh, et al. 2021). In the practice of mindfulness and cognitive defusion, an individual notices whatever ideas, feelings, or sensations come in the present moment, and allows their actions to not be dictated by the content of their thoughts, feelings, or experiences. In addition, identity is a knowledge of one's own experiences (past and present) without a desire to hold on to them, which is commonly labeled the "visual observation self."

Changes in the way a person with dementia thinks and behaves are unavoidable. Reductions in specific behaviors such as self-care and daily living tasks such as cooking and walking are observed because of reductions in both cognitive and physical ability. In individuals with dementia, dressing, grooming, transferring, feeding, washing, and toileting themselves may all be challenging. With this information, you can see that patients with dementia may have numerous errors, trouble communicating, and physical limitations, which can occur as the result of memory lapses, confusion, or challenges. The scope for management to adapt the quantity of workers to meet fluctuations in demand was highlighted by numerical flexibility, whereas functional flexibility, as previously stated, was how easily the activities performed by workers could be modified to match variations in the nature of that demand (Ali, et al. 2021). Associated about the exclamation point 'vital' in this method, Abdullah \& Anwar, (2021) offer the alternate term 'profound', and many others offer the term 'significant' (Omoraka, 2020) as alternative terms to better describe the everyday incidents that may be the focus of nursing research. This appears to be supported by the information which has been shared, as it appears from the aforementioned debate that, with a name change from 'critical' to 'revelatory' or 'significant', this strategy may be deemed even more broadly applicable. People who employ a flexible mind-set as well as the flexible-emotion theory make use of acceptance as a strategy for implementation of an alternative strategy for using experiential avoidance, 
which is illustrated by a pattern of conduct (Lee \& Lee, 2019). Mindfulness and cognitive diffusion is all about recognizing everything that comes to mind in the present moment, and acting in response to whatever emotions, ideas, or sensations appear. Also, one's identity includes both knowing who they are, and also letting go of that knowledge and not wanting to cling on to it. This is referred to as a "visual observation self." For some people with dementia, changes in thinking and behavior are inescapable. Cognitive and physical capacity are both reduced, which causes specific behaviors like self-care and daily living duties like as cooking and walking to be reduced. Even selfcare activities, such as clothing, grooming, transferring, feeding, showering, and toileting, can be difficult in adults with dementia. Because of this, you will find that patients with dementia could experience a multitude of blunders, communication problems, and physical difficulties that stem from memory lapses, disorientation, or other issues. In the instance of numerical flexibility, managers were given permission to make adjustments to the number of workers based on changing demand. Functional flexibility, on the other hand, is defined as the ease with which worker tasks can be modified to adjust to variations in the nature of the demand (Anwar, 2017). Mirsafian, (2019) provides the alternative term 'profound' as a synonym for 'vital' when describing ordinary experiences which are the subject of nursing study. According to the evidence supplied, it appears that a term change from 'critical' to 'revelatory' or 'significant' has led to a wider use of this method (Panagiotopoulos \& Karanikola, 2017).

\section{Negotiation}

In practically every sector of our everyday lives, negotiation techniques may be found. Every day we negotiate multiple agreements. For example, we frequently have to pick among several possible scenarios through interpersonal transactions such as buying a property, negotiating a new contract at work, or asking our spouse to go to the movies. The use of negotiation has expanded in recent years, with many experts agreeing that this will benefit employees. An effective pause comes after or before a key comment in the negotiation. To help the subject focus on the content of what the negotiator is saying, the pauses aid in drawing out the information that the negotiator is going to say. Both negotiating techniques cause the negotiation styles to be expressed in two different manners. An essential first step in ethical bargaining is locating one's interests and goals (Anwar \& Qadir, 2017). It takes a lot of research and thought into the needs and interests of the parties, creating many possible solutions, and, ultimately, working toward developing a stronger working relationship between the parties. When it comes to dividing the pie, almost all the time the pie that gets shared does both parties some good, but in most circumstances, the pie that gets divided gets larger (Anwar \& Climis, 2017), benefitting both sides. On the other hand, the idea of positional bargaining is focused on what both parties stand to gain and lose, whereas the focus of positional negotiation is centered on what both parties are likely to win and lose. This results in an agreement being reached by making a series of concessions for both parties, followed by a contest to see which party has the upper hand. Despite the fact that one person is believed to be able to finish the entire pie, the idea of dividing the pie to supply another person with more food is not seen as being possible. While there is no single method that will suit all talks, negotiators who are skilled will be able to apply several ways as well as have the capacity to adopt the appropriate strategy at all times (Ali, et al. 2021).

\section{Ethical Actions}

An institution's flexibility to sustain a commitment to ethical and socially responsible practices across multiple cultures is a possible source of competitive advantage (Silva $\&$ Soares, 2018). This section of the study draws on the resource-based theory of competitive advantage and expands on it by claiming that ethical capability may be a source of persistent competitive advantage. Ethics is so commonly regarded as a state of "right vs. wrong, or good vs. evil," although it is not even close to being correct. Ethics consists of a multi-stage process of first defining what one should do in a specific event, and then balancing both inner and exterior concerns such that the unique mixes of experience and learning of every individual is taken into consideration. Humans have to do a lot of thinking before they can operate in a morally right manner (Hameed \& Anwar, 2018). The basic concept of the profession's dedication to service and honesty is to engage in behaviour like this.

According to Sabir, et al. 2021), an efficient team activity should be developed around a set of unique organizational skills that are crucial for obtaining a competitive advantage. Resource-based theory was originally established in an attempt to explain how resource-based theory applies directly to human resource management as a source of competitive advantage. Even if designers adhere to ethical expectations and design a trustworthy, reliable, transparent, and honest autonomous system (through a true ethical design process), numerous ethical risks persist in the presence of human-machine symbiosis, which is typically found when considering intimate or close human/machine interaction. In our work, we define an ethical risk as a situation where the risk of exposing humans or leading to immoral machine behavior or machine behavior that is incongruent with societal expectations is present despite all 
the efforts that designers of societal structures have made to avoid these situations (Kucuk Bicer \& İlhan, 2020).

In this study, ethics is stated as including both the actions (which may include choosing and acting) that fit with society norms and the choices individuals make (including decisions) (including decisions). Perhaps the designer of human-machine systems, the system user, or the machine itself is questioning the ethical standards of behavior (ethical design), or the systems are exhibiting odd behavior (machine ethics) (Trentesaux \& Rault, 2017). From our perspective, there are two basic ethical frameworks in the literature: deontology (such as deciding/acting in accordance with moral principles) and consequentialism (deciding/acting in accordance with the probable moral impacts). Additionally, work has been done on studying spirituality connected to personal goals in everyday behavior (Abdullah, et al. 2017), workplace thoughts, behaviors, and interactions (Ali, et al. 2021), and transforming organizational culture by transforming leadership and employees (Gómez, et al. 2021).

\section{Compassion Skill}

It may well be simple to brush aside the value of nonverbal communication skills; nonetheless, when poor communication happens, it frequently incorporates weaknesses in nonverbal communication. Secondly, the patient's cultural background must always be considered when some of these abilities are being applied. While they may be appropriate and useful in some cultural contexts, they are totally inappropriate and meaningless in others. Though it is largely understood that compassion is a crucial attitudinal component of mindfulness practice (Aziz, et al. 2021), in general, MBIs do not expressly teach compassion. While compassion is largely taught through the teachings of the instructor, compassion is most definitely demonstrated in how the instructor interacts with the participants (Sorguli, et al. 2021). This creates an impact on participants in a way that encourages them to adopt the same compassionate demeanor in dealing with their own experiences. Mindfulness-based stress reduction teachers are given the opportunity to incorporate a metta meditation in which participants focus on feelings of love, warmth, and compassion for themselves and others during the silent retreat that occurs between weeks 6 and 7 of the program. This is optional, however. To expand access to treatments, mental health professionals have started developing online interventions in the hopes of reducing the number of the obstacles that prevent people from getting appropriate care. In instance, self-directed online treatments address multiple issues since they deal with all of them. Normative developmental transitions such as attending college are lifechanging experiences, and as such, are associated with discontinuities, departures from past roles, and the introduction of new patterns and functioning (Hamza, et al. 2021). While some people flourish with the recently gained independence and the greater potential for self-selection of activities and choices, others resist these new conditions. On the other hand, for some, a lack of coping abilities and institutional supports create a mismatch between their demands and the environment's affordances, which could potentially have a detrimental impact on their well-being (Makkos, et al. 2020).

When bad communication occurs, it typically involves problems in nonverbal communication. Another factor to consider is the patient's cultural background; if any of these abilities are used, it is critical that his or her history be taken into consideration. Some cultural contexts may find them useful, while they are completely irrelevant elsewhere. Though compassion is widely acknowledged to be an important attitude for mindfulness practice (Ahmed, et al. 2021), MBIs often do not describe or impart compassion training. Compassion is most clearly expressed through the instructor's interaction with participants (Ismael, et al. 2021). This influences individuals to adopt a caring attitude with regard to their personal experiences. MBSR teachers who have participated in a metta meditation exercise during their months 8 silent retreat have an option to add a mindfulness-based stress reduction lesson on feelings of love, warmth, and compassion for themselves and others. While not required, this option is available. The field of mental health is doing everything it can to increase access to treatments, and to this end, therapists are now designing online interventions in the hopes of cutting down on the number of obstacles that hinder people from accessing adequate care. Treating various problems using selfdirected online treatment has the advantage of dealing with a variety of problems at once. Life-changing experiences, and as such, transitions from old roles, and the introduction of new patterns and functioning are common with normative developmental transitions, such as going to college (Ermasova, et al. 2018). Some people enjoy having the extra freedom earned by increased autonomy and a wider range of possible activities and choices to chose from, while others reject these conditions. Others, in contrast, may face a mismatch between their emotional needs and the environment's physical features, which could negatively affect their overall well-being (Khati \& Kim, 2020).

\section{Accounting Information System}

Encompassing a system of physical and nonphysical interconnectedness, accounting information system (AIS) can act as a gateway that unites different subsystems or components, integrating financial and nonfinancial information and functioning as a means of converting 
information pertaining to a lack of financial resources into financial information. When it comes to systems for gathering, converting, and disseminating information, accounting systems must be capable of doing so (Sousa, 2017). The efficiency of the accounting information system installation depends on managerial commitment. The most crucial factors in the new "Accounting Information System" deployment's success are that it's easy for users to interact with, management is on board, and the objectives are defined clearly. Thorough preparation and fair expectations are two vital components of any successful project. After investigating the many promises connected to maintaining behavior management in order to help clients meet their goals and enhance the efficacy of the accounting information system, Additionally, Gardi, (2021) assert that maintaining the company's commitment to information technology and consistency of resources make it easier to use the assistance required for operations. Additionally, Indonesia must contend with difficulties, like a low quality of human resources, that may limit future economic progress (Ismael, et al. 2021).

\section{RESEARCH METHODOLOGY}

The article's purpose is to measure the impact of human resources management skills on accounting information quality in kurdistan public sector. To enable the study to measure human resource management skills at public sectors in Kurdistan region of Iraq, the researchers used five human resources management skills elements, first is communication skill, second is flexibility skill, third is negotiation skill, fourth is ethical action skill, and fifth is compassion skill. To assess the current study, the researchers used a quantitative research method in the form of a survey. The questionnaire was delivered at random to 84 administrative employees from several government departments in the Kurdistan region. The researchers, on the other hand, were able to collect 78 completed questionnaires. All questionnaire items were scored on a five-point Likert scale ranging from $1=$ Strongly Disagree, 2=Disagree, 3=Neutral, 4=Agree, and 5=Strongly Agree. After the completion of data gathering, all collected information are measure and examined by using were SPSS to determine the development of measure the impact of human resources management skills on accounting information quality in kurdistan public sector.

\section{Research model}

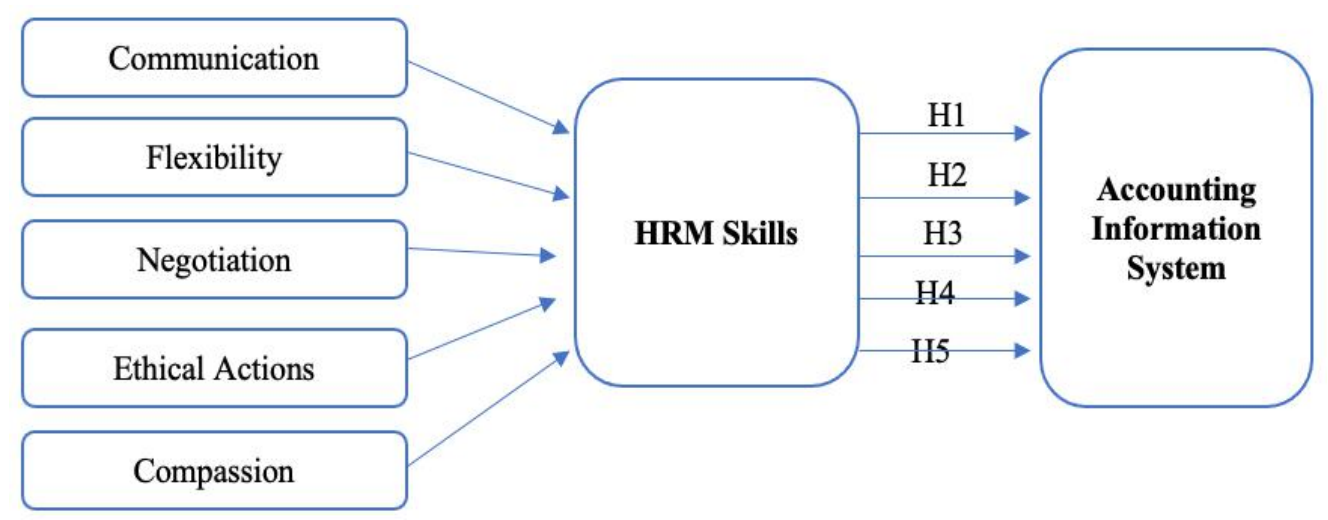

Fig.1: Research Model

\section{Research Hypotheses}

H1: Communication skill as human resource management skills has a positive and significant influence on accounting information system.

$\mathrm{H} 2$ : Flexibility skill as human resource management skills has a positive and significant influence on accounting information system.
H3: Negotiation skill as human resource management skills has a positive and significant influence on accounting information system.

H4: Ethical actions skill as human resource management skills has a positive and significant influence on accounting information system.

H5: Compassion skill as human resource management skills has a positive and significant influence on accounting information system. 


\section{DATA ANALYSIS}

Table 1- KMO and Bartlett Sphericity Test of Self-rating Items

\begin{tabular}{|c|c|c|c|c|c|}
\hline \multirow[t]{2}{*}{ Factors } & \multirow[t]{2}{*}{$\mathrm{N}$ of items } & \multirow[t]{2}{*}{$\mathrm{n}$} & \multirow[t]{2}{*}{ KMO } & \multicolumn{2}{|c|}{ Bartlett test } \\
\hline & & & & Chi-Square & Sig \\
\hline Communication skill & 8 & 78 & \multirow[t]{6}{*}{.711} & \multirow[t]{6}{*}{1.523} & \multirow[t]{6}{*}{.000} \\
\hline Flexibility skill & 7 & 78 & & & \\
\hline Negotiation skill & 9 & 78 & & & \\
\hline Ethical actions skill & 8 & 78 & & & \\
\hline Compassion skill & 7 & 78 & & & \\
\hline Accounting Information System & 10 & 78 & & & \\
\hline
\end{tabular}

Table (1) demonstrates the findings of KMO and Bartlett Sphericity for each variable (communication skill, flexibility, negotiation, ethical actions skill, compassion skill, and accounting information system). The results showed that the value of KMO is .711 which is greater than .001 , this concluded that the sample size used for the present article is effective and efficient. Moreover, the Chi-square $=1.523$ along with .000 significant level.

Table 2: Reliability analysis

\begin{tabular}{|l|c|l|c|}
\hline Factors & N of items & $\mathrm{n}$ & Cronbach's Alpha \\
\hline Communication skill & 8 & 78 & .731 \\
\hline Flexibility skill & 7 & 78 & .736 \\
\hline Negotiation skill & 9 & 78 & .741 \\
\hline Ethical actions skill & 8 & 78 & .761 \\
\hline Compassion skill & 7 & 78 & .722 \\
\hline Accounting Information System & 10 & 78 & .769 \\
\hline
\end{tabular}

Table (2) demonstrates the findings of 49 questions as follow (communication skill $=8$ questions, flexibility skill $=7$ questions, negotiation skill= 9 questions, ethical actions skill $=8$ questions, compassion skill= 7 questions, and accounting information system $=10$ questions). The study used reliability analysis; the results showed that communication skill $=.731$ as alpha value with 78 sample size for eight questions, flexibility skill $==.736$ as alpha value with 78 sample size for seven questions, negotiation skill $=.741$ as alpha value with 78 sample size for nine questions, ethical actions skill $=.761$ as alpha value with 78 sample size for eight questions, compassion skill=.722 as alpha value with 78 sample size for seven questions, and accounting information system $=.769$ as alpha value with 78 sample size for ten questions.

Table 3: Correlation Analysis

\begin{tabular}{|c|c|c|c|c|c|c|c|}
\hline \multicolumn{8}{|l|}{ Correlations } \\
\hline & & CS & FS & NS & EAS & COS & AIS \\
\hline \multirow[t]{3}{*}{ Communication skill } & $\begin{array}{l}\text { Pearson } \\
\text { Correlation }\end{array}$ & 1 & & & & & \\
\hline & Sig. (2-tailed) & & & & & & \\
\hline & $\mathrm{N}$ & 78 & & & & & \\
\hline Flexibility skill & $\begin{array}{l}\text { Pearson } \\
\text { Correlation }\end{array}$ & $.621^{* *}$ & 1 & & & & \\
\hline
\end{tabular}




\begin{tabular}{|c|c|c|c|c|c|c|c|}
\hline & Sig. (2-tailed) & .000 & & & & & \\
\hline & $\mathrm{N}$ & 78 & 78 & & & & \\
\hline \multirow[t]{3}{*}{ Negotiation skill } & $\begin{array}{l}\text { Pearson } \\
\text { Correlation }\end{array}$ & $.633^{* *}$ & $.639^{* *}$ & 1 & & & \\
\hline & Sig. (2-tailed) & .000 & .000 & & & & \\
\hline & $\mathrm{N}$ & 78 & 78 & 78 & & & \\
\hline \multirow[t]{3}{*}{ Ethical actions skill } & $\begin{array}{l}\text { Pearson } \\
\text { Correlation }\end{array}$ & $.705^{* *}$ & $.597^{* *}$ & $.644^{* * *}$ & 1 & & \\
\hline & Sig. (2-tailed) & .000 & .001 & .000 & & & \\
\hline & $\mathrm{N}$ & 78 & 78 & 78 & 78 & & \\
\hline \multirow[t]{3}{*}{ Compassion skill } & $\begin{array}{l}\text { Pearson } \\
\text { Correlation }\end{array}$ & $.661^{* *}$ & $.703^{* *}$ & $.721^{* *}$ & $.736^{* *}$ & 1 & \\
\hline & Sig. (2-tailed) & .000 & .001 & .000 & .000 & & \\
\hline & $\mathrm{N}$ & 78 & 78 & 78 & 78 & 78 & \\
\hline \multirow[t]{3}{*}{$\begin{array}{l}\text { Accounting Information } \\
\text { System }\end{array}$} & $\begin{array}{l}\text { Pearson } \\
\text { Correlation }\end{array}$ & $.632^{* *}$ & $.714^{* *}$ & $.709^{* * *}$ & $.638^{* *}$ & $.697^{* *}$ & 1 \\
\hline & Sig. (2-tailed) & .000 & .001 & .000 & .000 & .000 & \\
\hline & $\mathrm{N}$ & 78 & 78 & 78 & 78 & 78 & 78 \\
\hline
\end{tabular}

Table (3) demonstrates the correlation between (communication skill, flexibility, negotiation, ethical actions skill, and compassion skill) and accounting information system. The findings showed that as for communication skill and accounting information system's value is $.632 * *$, as for flexibility skill and accounting information system's value is $.714^{* *}$, as for negotiation skill and accounting information system's value is . $709^{* *}$, as for ethical action skill and accounting information system's value is $.638^{* *}$, as for compassion skill and accounting information system's value is .697**. This means that there is significant correlation between (communication skill, flexibility, negotiation, ethical actions skill, and compassion skill) and accounting information system.

Table 4-Hierarchal Multiple Regression

\begin{tabular}{|c|c|c|c|c|c|c|}
\hline \multicolumn{7}{|c|}{ Coefficients } \\
\hline \multirow{2}{*}{\multicolumn{2}{|c|}{ Model }} & \multicolumn{2}{|c|}{$\begin{array}{l}\text { Unstandardized } \\
\text { Coefficients }\end{array}$} & \multirow{2}{*}{$\begin{array}{l}\text { Standardized } \\
\text { Coefficients } \\
\text { Beta }\end{array}$} & \multirow[t]{2}{*}{$\mathrm{t}$} & \multirow[t]{2}{*}{ Sig. } \\
\hline & & & & & & \\
\hline \multirow[t]{6}{*}{1} & (Constant) & 1.636 & .3021 & & 1.325 & .000 \\
\hline & Communication skill & .599 & .041 & .632 & 1.365 & .000 \\
\hline & Flexibility skill & .603 & .012 & .611 & 1.333 & .000 \\
\hline & Negotiation skill & 639 & .17 & .642 & 1.747 & .000 \\
\hline & Ethical actions skill & .644 & .35 & .649 & 1.987 & .000 \\
\hline & Compassion skill & .655 & .33 & .661 & 1.545 & .000 \\
\hline
\end{tabular}

Table (4), shows a hierarchal multiple regression measure to the impact of (communication skill, flexibility, negotiation, ethical actions skill, and compassion skill) on accounting information system. The results showed that as 
for the impact of communication skill on accounting information system was found the value of Beta is .632 with significant level .000 this indicated that first research hypothesis is supported which is Communication skill as human resource management skills has a positive and significant influence on accounting information system. As for the impact of Flexibility skill on accounting information system was found the value of Beta is .611 with significant level .000 this indicated that second research hypothesis is supported which is Flexibility skill as human resource management skills has a positive and significant influence on accounting information system. As for the impact of Negotiation skill on accounting information system was found the value of Beta is .642 with significant level .000 this indicated that third research hypothesis is supported which is Negotiation skill as human resource management skills has a positive and significant influence on accounting information system. As for the impact of Ethical actions skill on accounting information system was found the value of Beta is .649 with significant level .000 this indicated that fourth research hypothesis is supported which is Ethical actions skill as human resource management skills has a positive and significant influence on accounting information system, and lastly, as for the impact of Compassion skill on accounting information system was found the value of Beta is .661 with significant level .000 this indicated that fifth research hypothesis is supported which is Compassion skill as human resource management skills has a positive and significant influence on accounting information system.

\section{CONCLUSION}

Operation complications that involve damage to internal organs or major vessels (such as intestinal perforation, necrosis, or embolization) depend to a considerable part on the intricacy of the procedure, the proximity of these structures to the operative field, and the surgical skills of the surgeon. While surgical training focuses a high focus on the need of avoiding complications, trainees rarely receive instruction on how to handle difficulties when they occur. Once we establish that effective management requires crisis management ability on the part of the surgeon, and that a surgeon's history and experience also contribute to that outcome, different outcomes are possible. While these cases are based on anecdote and have no scientific validation, the knowledge used to manage these situations is derived from observation of a mentor who is also dealing with a similar situation, or from one's own personal experience, where the surgeon might have learned by making mistakes. Thus, such learning is a matter of chance and dependent on having had to cope with comparable situations in the past.
The intricacy of the surgery, the proximity of these structures to the operational field, and the surgical skills of the surgeon are of substantial importance when it comes to problems involving internal organs or major artery (such as intestinal perforation, necrosis, or embolization). During surgical training, there is a great emphasis on avoiding complications, but students are not taught how to respond when problems arise. With the aid of research, we now know that a surgeon who possesses crisis management skills can successfully lead a healthcare organization during difficult situations, and that a surgeon's history and experience contribute to that. As a result, it is feasible to produce varied outcomes. These scenarios are based on anecdote and have no scientific confirmation, however when managing these situations, you can learn via observation of a mentor or by making mistakes on your own. In other words, such learning is simply a matter of chance and depends on a person having had to cope with events identical to their current problem.

The study used a hierarchal multiple regression measure to the impact of (communication skill, flexibility, negotiation, ethical actions skill, and compassion skill) on accounting information system. The results showed that as for the impact of communication skill on accounting information system was found the value of Beta is .632 with significant level .000 this indicated that first research hypothesis is supported which is Communication skill as human resource management skills has a positive and significant influence on accounting information system. As for the impact of Flexibility skill on accounting information system was found the value of Beta is .611 with significant level .000 this indicated that second research hypothesis is supported which is Flexibility skill as human resource management skills has a positive and significant influence on accounting information system. As for the impact of Negotiation skill on accounting information system was found the value of Beta is .642 with significant level .000 this indicated that third research hypothesis is supported which is Negotiation skill as human resource management skills has a positive and significant influence on accounting information system. As for the impact of Ethical actions skill on accounting information system was found the value of Beta is .649 with significant level .000 this indicated that fourth research hypothesis is supported which is Ethical actions skill as human resource management skills has a positive and significant influence on accounting information system, and lastly, as for the impact of Compassion skill on accounting information system was found the value of Beta is .661 with significant level .000 this indicated that fifth research hypothesis is supported which is Compassion skill as human resource management skills has a positive and significant influence on accounting information system. 


\section{REFERENCES}

[1] Sousa, M. J. (2017). Human Resources Management Skills Needed by Organizations. In Leadership, Innovation and Entrepreneurship as Driving Forces of the Global Economy (pp. 395-402). Springer, Cham.

[2] Mazurchenko, A., \& Maršíková, K. (2019). DigitallyPowered Human Resource Management: Skills and Roles in the Digital Era. Acta Informatica Pragensia, 8(2), 72-87.

[3] Gardi, B. (2021). Investigating the effects of Financial Accounting Reports on Managerial Decision Making in Small and Medium-sized Enterprises. Turkish Journal of Computer and Mathematics Education (TURCOMAT), 12(10), 2134-2142.

[4] Ismael, N. B., Sorguli, S., Aziz, H. M., Sabir, B. Y., Hamza, P. A., Gardi, B., \& Al-Kake, F. R. A. (2021). The Impact of COVID-19 on Small and Medium-Sized Enterprises in Iraq. Annals of the Romanian Society for Cell Biology, 24962505.

[5] Sorguli, S. H., \& Al-Kake, F. R. A. (2020). The impact of Accounting Information System on Internal Controls in Iraq. Solid State Technology, 63(5), 7024-7036.

[6] Al Shobaki, M. J., Naser, S. S. A., Amuna, Y. M. A., \& El Talla, S. A. (2017). Impact of Electronic Human Resources Management on the Development of Electronic Educational Services in the Universities. International Journal of Engineering and Information Systems, 1(1), 1-19.

[7] Tambe, P., Cappelli, P., \& Yakubovich, V. (2019). Artificial intelligence in human resources management: Challenges and a path forward. California Management Review, 61(4), $15-42$.

[8] Gardi, B. (2021). THE EFFECTS OF COMPUTERIZED ACCOUNTING SYSTEM ON AUDITING PROCESS: A CASE STUDY FROM NORTHERN IRAQ. Available at SSRN 3838327.

[9] Damit, D. H. D. A., Harun, A., Martin, D., Othman, B., \& Ahmad, H. (2019). What makes a non-Muslim purchase halal food in a Muslim country? An application of theory of planned behaviour. Management Science Letters, 9(12), 2029-2038.

[10] Ali, B. J., \& Anwar, G. (2021). Factors Influencing the Citizens' Acceptance of Electronic Government. International Journal of Engineering, Business and Management, $\quad 5(1), \quad 48-60$. https://doi.org/10.22161/ijebm.5.1.5

[11] De Mauro, A., Greco, M., Grimaldi, M., \& Ritala, P. (2018). Human resources for Big Data professions: A systematic classification of job roles and required skill sets. Information Processing \& Management, 54(5), 807-817.

[12] HAKIM, H., \& KESSENTINI, A. (2017). Training and skills/career management: Case of involvement in the ERP dynamics Nav. Training, 8(1), 181-195.

[13] Kutnjak, A., Križanić, S., \& Pihir, I. (2019). Educational and practical view of knowledge, skills and experience needed by a Chief Digital Officer. In Proceedings of the 11th International Conference on Education and New Learning Technologies EDULEARN (pp. 5711-5718).

[14] Saleh, P. F., Ali, B. J., Akoi, S., Najmalddin, B., Ali, R. S., $\&$ Anwar, G. (2021). Factors affecting the Success of Female
Entrepreneurs in Kurdistan. International journal of Engineering, Business and Management (IJEBM), 5.

[15] Ali, B. J., Saleh, P. F., Akoi, S., Abdulrahman, A. A., Muhamed, A. S., Noori, H. N., \& Anwar, G. (2021, May). Impact of Service Quality on the Customer Satisfaction: Case study at Online Meeting Platforms. In Ali, BJ, Saleh, Akoi, S., Abdulrahman, AA, Muhamed, AS, Noori, HN, Anwar, G.(2021). Impact of Service Quality on the Customer Satisfaction: Case study at Online Meeting Platforms. International journal of Engineering, Business and Management (Vol. 5, No. 2, pp. 65-77).

[16] Abdullah, N. N., \& Anwar, G. (2021). An Empirical Analysis of Natural Gas as an Alternative Fuel for Internal Transportation. International Journal of English Literature and Social Sciences, 6(1).

[17] Omoraka, A. E. (2020). A principal component analysis of supply chain management skills for the Nigerian construction industry. International Journal of Construction Management, 1-9.

[18] Lee, G. Y., \& Lee, D. Y. (2019). Effects of a life skills-based sexuality education programme on the life-skills, sexuality knowledge, self-management skills for sexual health, and programme satisfaction of adolescents. Sex Education, 19(5), 519-533.

[19] Anwar, K. (2017). Leading Construction Project Teams: The Effectiveness of Transformational Leadership in Dynamic Work Environments in Kurdistan. International Journal of Advanced Engineering, Management and Science, 3(10), 239925

[20] Mirsafian, H. (2019). Effect of an Educational Intervention of Seven Quantum Management Skills on Job Satisfaction, Job Involvement, and Organizational Commitment of Physical Education Teachers. Sport Management Studies, 11(53), 219-236.

[21] Panagiotopoulos, G., \& Karanikola, Z. (2017). Skills and sentimental intelligence: A new dimension in employability. European Journal of Educational and Development Psychology, 5(5), 37-44.

[22] Anwar, K., \& Qadir, G. H. (2017). A Study of the Relationship between Work Engagement and Job Satisfaction in Private Companies in Kurdistan. International Journal of Advanced Engineering, Management and Science, 3(12), 239944.

[23] Anwar, K., \& Climis, R. (2017). Analyzing the relationship between types of advertisement and customer choice: a study of retailer stores in erbil. The International Journal of Accounting and Business Society, 25(2), 43-52.

[24] Ali, B. J., Saleh, Akoi, S., Abdulrahman, A. A., Muhamed, A. S., Noori, H. N., Anwar, G. (2021). Impact of Service Quality on the Customer Satisfaction: Case study at Online Meeting Platforms. International journal of Engineering, Business and Management, 5(2), 65-77. https://dx.doi.org/10.22161/ijebm.5.2.6

[25] Silva, A. M. R. A., \& Soares, C. A. P. (2018). Competencies and skills of site managers from the point of view of human resources professionals and site managers. Business Management Dynamics, 7(9), 1. 
[26] Hameed, A. A., \& Anwar, K. (2018). Analyzing the Relationship between Intellectual Capital and Organizational Performance: A Study of Selected Private Banks in Kurdistan. International Journal of Social Sciences \& Educational Studies, 4(4), 39.

[27] Sabir, B. Y., Othman, B .J., Gardi, B., Ismael, N. B., Hamza, P. A., Sorguli, S., Aziz, H. M., Ahmed, S. A., Ali, B. J., Anwar, G. (2021). Administrative Decentralization: The Transfer of Competency from The Ministry of Education to General Directorates. International Journal of Rural Development, Environment and Health Research, 5(3), 113. https://doi.org/10.22161/ijreh.5.3.1

[28] Kucuk Bicer, B., \& İlhan, S. (2020). Self-evaluation of the success of the main core skills taught in six years of medical education. European Journal of Public Health, 30(Supplement_5), ckaa166-669.

[29] Abdullah, M. S., Toycan, M., \& Anwar, K. (2017). The cost readiness of implementing e-learning. CUSTOS E AGRONEGOCIO ON LINE, 13(2), 156-175.

[30] Ali, B. J., Anwar, G., Gardi, B., Othman, B. J., Aziz, H. M., Ahmed, S. A., Hamza, P. A., Ismael, N. B., Sorguli, S., Sabir, B. Y. (2021). Business Communication Strategies: Analysis of Internal Communication Processes. Journal of Humanities and Education Development, 3(3), 16-38. https://doi.org/10.22161/jhed.3.3.4

[31] Gómez, M. Á., Herrera, R. F., Atencio, E., \& Munoz-La Rivera, F. C. (2021). Key Management Skills for Integral Civil Engineering Education. Int. J. Eng. Pedagog., 11(1), 64-77.

[32] Aziz, H. M., Othman, B. J., Gardi, B., Ahmed, S. A., Sabir, B. Y., Ismael, N. B., Hamza, P. A., Sorguli, S., Ali, B. J., Anwar, G. (2021). Employee Commitment: The Relationship between Employee Commitment And Job Satisfaction. Journal of Humanities and Education Development, 3(3), 54-66. https://doi.org/10.22161/jhed.3.3.6

[33] Sorguli, S., Gardi, B., Othman, B.J., Aziz, H. M., Ahmed, S. A., Sabir, B. Y., Ismael, N. B., Hamza, P. A., Ali, B. J., Anwar, G. (2021) Innovation: Knowledge Management in the Innovating Industries, 6(3), 10-23. https://dx.doi.org/10.22161/eec.63.2

[34] Hamza, P. A., Othman, B. J., Gardi, B., Sorguli, S., Aziz, H. M., Ahmed, S. A., Sabir, B. Y., Ismael, N. B., Ali, B. J., Anwar, G. (2021). Recruitment and Selection: The Relationship between Recruitment and Selection with Organizational Performance. International Journal of Engineering, Business and Management, 5(3), 1-13. https://doi.org/10.22161/ijebm.5.3.1

[35] Makkos, A., Fehér, Á., \& Benyák, A. (2020). Consultancy skills in the light of emotional intelligence and communication skills of students specialised in human resources consultancy. KÉPZÉS ÉS GYAKORLAT: TRAINING AND PRACTICE, 18(1-2), 101-112.

[36] Ahmed, S. A., Othman, B. J., Gardi, B., Sabir, B. Y., Ismael, N. B., Hamza, P. A., Sorguli, S., Aziz, H. M., Ali, B. J., Anwar, G. (2021). Students' Attitudes towards Learning English in the Kurdistan region of Iraq. International Journal of English Literature and Social Sciences, 6(3), 072-087. https://doi.org/10.22161/ijels.63.11

[37] Ismael, N. B., Othman, B. J., Gardi, B., Hamza, P. A., Sorguli, S., Aziz, H. M., Ahmed, S. A., Sabir, B. Y., Ali, B. J., Anwar, G. (2021). The Role of Training and Development on Organizational effectiveness. International Journal of Engineering, Business and Management, 5(3), 15-24. https://doi.org/10.22161/ijebm.5.3.3

[38] Ermasova, N., Nguyen, L. D., Clark, D., \& Ermasov, S. (2018). The Management Skills of Russians: Do Work, Management, and Government Experiences Matter?. Public Organization Review, 18(3), 299-312.

[39] Khati, P., \& Kim, D. (2020). Human Resources and Skills as Drivers in Developing the Food Processing Sector: A Special Reference to Assam. The Journal of Indian and Asian Studies, 1(02), 2050011. 